International Business and Global Economy 2018, no. 37, pp. 98-113

Biznes międzynarodowy w gospodarce globalnej 2018, nr 37, s. 98-113

Edited by the Institute of International Business, University of Gdańsk

ISSN 2300-6102

e-ISSN 2353-9496

DOI 10.4467/23539496IB.18.007.9380

Andżelika Kuźnar
Jerzy Menkes

Szkoła Główna Handlowa w Warszawie

\title{
Instytucje polityki „post-pivot” w Azji - wybrane aspekty
}

Region Pacyfiku konfrontuje się z wieloma wyzwaniami, stanowiącymi o jego wadze w stosunkach międzynarodowych. Celem badania jest analiza możliwości współpracy państw tego regionu - bliskich geograficznie, ale posiadających odmienne doświadczenia historyczne oraz różnych pod względem ustroju społeczno-polityczno-gospodarczego w sytuacji niestabilności polityki USA. Zmiany w tej polityce stanowią źródło turbulencji w regionie oraz stosunkach transregionalnych. W interdyscyplinarnym badaniu ekonomiczno-prawniczym wykorzystujemy metody ekonomicznej analizy jakościowej i ilościowej oraz prawnicze metody studiów nad instytucjami międzynarodowymi. Pozytywnie weryfikujemy tezę, że trwała i głęboka współpraca regionalna i transregionalna jest zdeterminowana reprezentowaniem wspólnych wartości, a sama bliskość geograficzna nie wystarcza, by taka współpraca miała miejsce. Barierą dla współpracy może okazać się niezdolność do przepracowania doświadczeń z przeszłości oraz niestabilność wynikająca m.in. ze zmian $w$ polityce USA.

Słowa kluczowe: post-pivot, wspólne wartości, Partnerstwo Transpacyficzne (TPP)

Klasyfikacja JEL: F13, F53, K33, N45, O15

\section{Institutions of "post-pivot" policy in Asia - selected aspects}

The Pacific region is confronted with many challenges that determine its importance in international relations. The aim of the study is to analyse the possibilities of cooperation of countries in this region - geographically close but with different historical experiences and differing in terms of socio-political and economic systems at the time of instability of US politics. Changes in this policy are a source of turbulence in the region and transregional relations. In interdisciplinary economic and legal research we use methods of economic qualitative and quantitative analysis as well as legal methods of studies on international institutions. We positively verify the thesis that lasting and deep regional and transregional cooperation is determined by the representation of common values, and geographic proximity alone is not enough for such cooperation to take place. The barrier for the cooperation may be the inability to work through the past experience and instability, resulting from the changes in US policy.

Keywords: post-pivot, common values, Trans-Pacific Partnership (TPP)

JEL classification: F13, F53, K33, N45, O15 


\section{Wprowadzenie}

Waga regionu Pacyfiku w stosunkach międzynarodowych jest wypadkową różnorodnych czynników ${ }^{1}$. Część z nich jest istotna z punktu widzenia stabilności porządku międzynarodowego - bezpieczeństwa międzynarodowego. „Spory lub sytuacje” w regionie Pacyfiku mogą "zagrażać pokojowi i bezpieczeństwu międzynarodowemu" [Karta Narodów Zjednoczonych, 1945, art. 34]. Na rzecz przypisywania doniosłości zagrożeniom mającym źródło w tym regionie przemawia zarówno przeszłość, jak i teraźniejszość. Wojna japońsko-rosyjska stanowiła preludium I wojny światowej; ujawniając słabość Rosji, zachęciła do zamachu na porządek kongresu wiedeńskiego. Japońska aneksja Mandżurii w 1931 r. była pierwszym działaniem zbrojnym II wojny światowej. W tym regionie $w$ drugiej połowie XX w. miała miejsce jedyna bezpośrednia konfrontacja zbrojna supermocarstw (w wojnach koreańskiej i wietnamskiej). Tego obrazu dopełniają wojny pomiędzy Indiami i Pakistanem oraz Wietnamem i Kambodżą. Dodatkowo istotne jest, że doświadczeń nie można zamknąć w pudełku z etykietą "przeszłość”, jako że np. Japonia ani nie przepracowała wojennej przeszłości, ani w stosunkach z ofiarami nie zbudowała pojednania. Toczy również spór z Rosją o Wyspy Kurylskie. Państwa regionu - wśród nich te dysponujące bronią jądrową - kwestionują terytorialne status quo i podejmują próby jego zmiany z użyciem siły. Korea Płn. odrzuca ład międzynarodowy oparty na zasadach Karty Narodów Zjednoczonych i grożąc sąsiadom, obniża próg użycia broni jądrowej. Niebezpieczną specyfikę regionu uzupełnia fakt, że dwa zlokalizowane w nim mocarstwa - Indie i Chiny - nie są (w powszechnie przyjętym znaczeniu) państwami, a cywilizacjami [Pye, 1990; Johnston, 1995, s. 32-64]. Ten niepełny katalog wyzwań skłania zarówno do monitorowania procesów i zdarzeń $\mathrm{w}$ regionie, jak i do przypisywania szczególnego znaczenia relacjom transregionalnym.

Celem badania jest analiza możliwości współpracy państw bliskich geograficznie, ale różnych $\mathrm{w}$ sferze ustroju społeczno-polityczno-gospodarczego, które dzieli także historia. Analizujemy konsekwencje zmian i niestabilności polityki USA dla współpracy z azjatyckimi sojusznikami i tych sojuszników między sobą. Podejmujemy próbę określenia strategii politycznej USA i możliwości jej realizacji z uwzględnieniem reakcji aliantów.

W interdyscyplinarnym badaniu ekonomiczno-prawniczym wykorzystujemy metody ekonomicznej analizy jakościowej i ilościowej oraz prawnicze metody studiów nad instytucjami międzynarodowymi. Weryfikacji zostaje poddana teza,

1 Prezydent Dwight D. Eisenhower, komentując w trakcie konferencji prasowej 7 kwietnia $1954 \mathrm{r}$. strategiczne znaczenie Indochin dla „wolnego świata”, wskazał na groźbę „efektu domina” w przypadku utraty któregokolwiek państwa [Eisenhower, 1954]. 
że trwała i głęboka współpraca transregionalna jest zdeterminowana reprezentowaniem wspólnych wartości przez USA i ich sojuszników w regionie Pacyfiku. W tym celu wybieramy i analizujemy wskaźniki, które naszym zdaniem świadczą o reprezentowaniu przez państwa wspólnych wartości. Stawiamy hipotezę, że zmiana polityki USA wobec regionu będzie jedynie źródłem niestabilności.

Przeciwstawiając zawirowania spowodowane polityką USA stabilnym fundamentom sojuszu USA-UE, z należącymi do zachodniej hemisfery państwami Azji Wschodniej i Południowo-Wschodniej, wskazujemy na USA jako partnera koniecznego, którego w tej roli Chiny - w dającej się przewidzieć perspektywie - nie mogą zastąpić.

Swoistym potwierdzeniem takiej prognozy są dane przedstawione na rysunku 1, które wyraźnie wskazują, iż preferencje opinii publicznej, badanej w 2015 r. w kilkunastu krajach regionu Pacyfiku, skłaniają się ku utrzymywaniu silniejszych więzi gospodarczych z USA niż z Chinami. Istotny jest tu oczywiście bezpośredni związek odległości geograficznej i preferencji partnera. Podczas gdy sąsiedzi USA - Meksyk i Kanada - zdecydowanie preferują więzi z USA, a nie z Chinami, odwrotna sytuacja występuje w Australii i Malezji. Chile i Peru również skłaniają się ku kontaktom z USA, choć w sposób bardziej umiarkowany. W przypadku Australii znaczenie przypisywane stosunkom z Chinami nie odzwierciedla alternatywy rozłącznej w postrzeganiu tych relacji. Jedynym wyjątkiem jest Wietnam, sąsiadujący z Chinami, nad którego stosunkiem do Chin ciąży przeszłość.

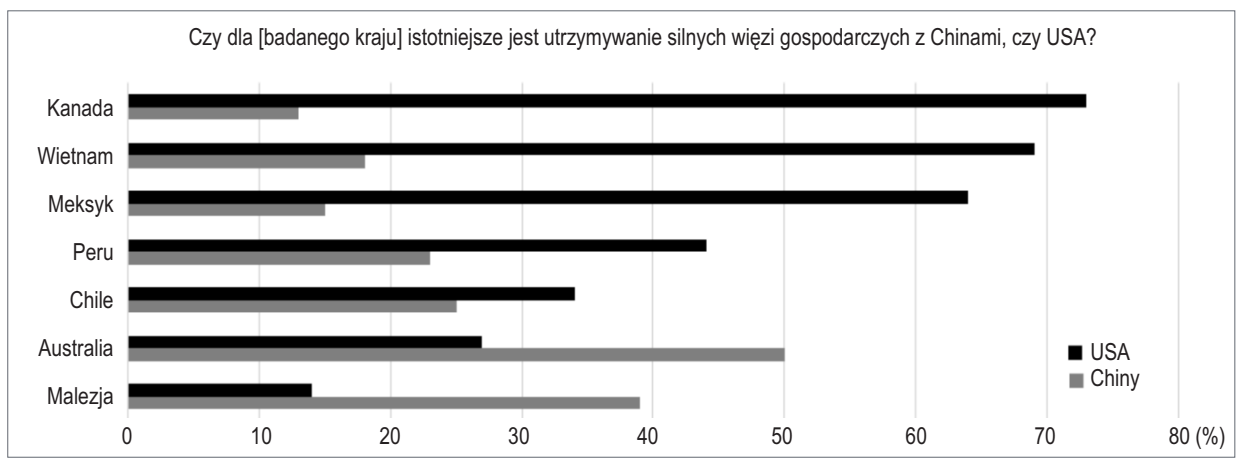

Uwaga: Badanie nie zostało przeprowadzone w pozostałych państwach TPP, tj. Brunei, Japonii, Nowej Zelandii i Singapurze.

Rysunek 1. Postrzeganie więzi z Chinami i USA przez opinię publiczną w wybranych państwach TPP (2015 r.)

Źródło: [Pew Global Attitudes \& Trends Question Database, 2018]. 


\section{Polityka USA w regionie Pacyfiku}

Od początku sprawowania urzędu prezydenta Donald J. Trump realizuje zapowiedzi zmiany polityki amerykańskiej [America First Foreign Policy, 2017]. Zmiana w polityce wobec regionu Pacyfiku miała obejmować wycofanie się z transpacyficznych porozumień wielostronnych w sferze gospodarczo-społecznej, kontestację współpracy w sferze bezpieczeństwa, podważenie bezwarunkowego charakteru gwarancji bezpieczeństwa dla państw regionu ${ }^{2}$ oraz odrzucenie paradygmatu wolnego handlu.

W odniesieniu do regionu Pacyfiku nową politykę zapoczątkowało wypowiedzenie 23 stycznia 2017 r. Partnerstwa Transpacyficznego (Trans-Pacific Partnership - TPP) ${ }^{3}$ [Presidential Memorandum, 2017]. Tym aktem prezydent zanegował długookresową strategię USA - dążenie do otwarcia Transpacyficznej umowy o strategicznym partnerstwie gospodarczym (Trans-Pacific Strategic Economic Partnership Agreement - TPSEP, P4), łączącej Brunei, Chile, Nową Zelandię i Singapur, na nowe państwa i nadania jej charakteru transpacyficznego. Do celu tego dążyli konsekwentnie od stycznia 2008 r. demokraci i republikanie. Racjonalność gospodarcza decyzji USA o wycofaniu się z TTP jest wątpliwa wobec korzystnych prognoz [USITC, 2016; World Bank, 2016, s. 219-255], nie równoważonych wagą krytyki [Capaldo, 2015; Capaldo, Izuriet, Sundaram, 2016] ${ }^{4}$. Zakładając, że o efektach gospodarczych umowy można dyskutować, nie ulega wątpliwości jej korzystny wpływ na pozycję geopolityczną USA [Green, Goodman, 2015, s. 19-34; Naughtoton i in., 2015].

Dodatkowo formuła polityczno-prawna wystąpienia budzi wątpliwości co do znajomości przez administrację Donalda Trumpa reguł i mechanizmów polityki międzynarodowej. $\mathrm{W}$ swoim memorandum prezydent zapowiedział dążenie do sprawiedliwych i gospodarczo korzystnych umów handlowych poprzez negocjowanie dwustronnych umów handlowych mających na celu promowanie amerykańskiego przemysłu, ochronę pracowników i wzrost płac w USA. Abstrahował więc zarówno od zdolności USA do zawierania umów międzynarodowych, jak i czasu koniecznego do zawarcia umów bilateralnych ${ }^{5}$.

Jedyną korzyścią z wystąpienia USA z TPP z punktu widzenia zachodniej hemisfery jest podtrzymanie woli współpracy „11”. Po wycofaniu się USA, w listopadzie 2017 r. pozostałe państwa zawarły Comprehensive and Progressive Agreement

2 Prezydent poruszał kwestę obowiązku udziału w kosztach zapewnienia bezpieczeństwa [Baker, 2017]. Bezpośrednio o warunkowości gwarancji bezpieczeństwa: [Sanger, Haberman, 2016].

3 Plurilateralna umowa regulująca zasady handlu, podpisana 4 lutego 2016 r. przez: Australię, Brunei, Chile, Kanadę, Japonię, Malezję, Meksyk, Nową Zelandię, Peru, Singapur, USA i Wietnam.

4 Krytyka metody zob. [Erixon, Bauer, 2015].

5 Np. negocjacje TPP trwały 8 lat. 
for Trans-Pacific Partnership (CPTTP, TPP11). Porozumienie to stanowi fundament instytucjonalizacji współpracy regionalnej. Może zapoczątkować integrację, wychodzącą od pojednania pomiędzy państwami, które dzieli przeszłość. TPP11 okazuje się również atrakcyjne dla innych państw regionu.

Wagi TTP - i roli w nim USA - nie sposób przecenić. Dwanaście państw-stron umowy miało ok. 25-procentowy udział w światowym handlu dobrami i usługami, prawie 40-procentowy w światowym PKB (mierzonym nominalnie) i 11-procentowy w światowej populacji [Palit, 2014]. Wycofanie się USA z TPP zmienia te statystyki (handel - 10 p.p., PKB - 21 p.p., populacja - 4,5 p.p.), zmniejszając potencjał ekonomiczny ugrupowania. Może on zostać jednak wzmocniony dzięki przystąpieniu kolejnych państw. Taki zamiar deklarują Korea Płd., Bangladesz, Filipiny, Indie, Kambodża, Kolumbia, Indonezja, Laos, Sri Lanka oraz Tajlandia. Również Wielka Brytania w obliczu brexitu wykazała zainteresowanie współpracą z TPP [Gregory, 2018]. Wystąpienie USA z TPP zmusza również państwa regionu do wzięcia - $\mathrm{w}$ większym zakresie - swojego losu w swoje ręce, co sprzyja zmniejszaniu zależności od Chin.

Może się okazać, że USA nie odzyskały możliwości kształtowania stosunków $\mathrm{w}$ reżimie umów bilateralnych, a staną wobec konieczności negocjowania $\mathrm{z}$ „11”. Oczywiście decyzja Trumpa nie zamknęła drzwi do współpracy. Perspektywa powrotu do niej okazała się bliższa niż mogło się wydawać. W styczniu 2018 r. Trump obwieścił możliwość zmiany stanowiska USA [CNBC, 2018].

Nowa polityka administracji USA okazała się nie tylko nieskuteczna, ale i niekonsekwentna. Zadecydowały o tym czynniki, których Trump nie uwzględnił w wystarczającym stopniu przy jej wyznaczaniu. Konfrontacyjna polityka Korei Płn., demonstrującej zdolność do militarnego wykorzystania potencjału nuklearnego, postawiła USA wobec konieczności natychmiastowego potwierdzenia gwarancji bezpieczeństwa dla Korei Płd. i Japonii, bez wzajemności z ich strony w postaci wzrostu udziału w kosztach bezpieczeństwa [Collinson, 2017]. To samo wyzwanie zmusza USA do współpracy z Chinami. Reaktywność polityki USA w regionie Pacyfiku jest aż nadto widoczna. Ilustrują to stosunki z Chinami. Z jednej strony USA dążą do współpracy z nimi w odniesieniu do problemów strategicznych (m.in. Korea Płn.), z drugiej zaś podejmują działania, które mogą zapoczątkować wojnę handlową 6 .

Mimo że trudno analizować politykę niestabilną, odróżnić strategię od taktyki, a trend długookresowy od jednorazowego zdarzenia, to w odniesieniu do polityki administracji Trumpa można wskazać zarówno fakt, że zapowiedzi w odniesieniu do strategii zostały wielokrotnie podważone, jak i kamienie milowe zmian tej

622 stycznia 2018 r. podniesiono (w ramach Trade Act of 1974) cła na panele słoneczne (do 30\%) i pralki (do 50\%). Jest to kolejne - po cłach antydumpingowych na wyroby aluminiowe - uderzenie w Chiny. 
polityki. Z tego punktu widzenia istotne znaczenie przypisujemy wizycie prezydenta w pięciu państwach azjatyckich w listopadzie 2017 r. (Japonia, Korea Płd., Chiny, Wietnam i Filipiny) i wystąpieniu w trakcie szczytu APEC (10 listopada 2017 r.). W Remarks at APEC CEO Summit [2017] zaprezentował on wizję „swobodnego i otwartego Indo-Pacyfiku”, służącą umacnianiu „więzi przyjaźni i handlu pomiędzy wszystkimi narodami Indo-Pacyfiku”, w której handel będzie oparty na fundamencie „sprawiedliwości i wzajemności”. Do zasad współpracy zaliczył „oczekiwanie, że rynki będą otwarte w równym stopniu po obu stronach, i że to prywatny przemysł, a nie rządy, będą kierować inwestycjami". Jednoznacznie wskazuje to, że USA w polityce azjatyckiej odbyły podróż od „pivot to Asia” przez neoizolacjonizm ku strategii Indo-Pacyfik („post-pivot”) [szerzej: Cronin, 2017]. Nic nie gwarantuje jednak ani że kolejny zwrot nie nastąpi, ani że ta oferta zostanie przyjęta.

\section{Azja w polityce USA}

Od końca II wojny światowej USA tworzyły strefę wpływów w regionie Azji Wschodniej, Południowo-Wschodniej i na Pacyfiku w celu wzmacniania stabilności w świecie i budowy zapory chroniącej region przed zdominowaniem przez „komunistów”. U źródeł amerykańskiego dążenia do gospodarczej, wojskowej i społecznej obecności w regionie Azji leży przekonanie o potencjalnych negatywnych konsekwencjach wytworzenia próżni w dowolnym zakątku świata. Globalny wymiar pozycji USA wymaga ipso facto globalnej obecności. Zarazem stała obecność jest efektywniejszym sposobem prowadzenia polityki niż obecność w odpowiedzi na wyzwania pretendenta regionalnego lub globalnego dążącego do podważenia pozycji USA i zbudowania imperium. Wielość celów decydowała o korzystaniu z różnych narzędzi w realizacji tej polityki. Jednocześnie USA w regionie Pacyfiku przywiązywały większą wagę do lojalności sojusznika niż do wspólnoty wartości. Często pragmatyzm USA osiągał wymiar amoralności , a kryterium wsparcia rządów wyznaczyła maksyma "to sukinsyn, ale nasz sukinsyn" .

Niezależnie od tego, czy USA w polityce zagranicznej kontynuowały wilsonowski idealizm instytucjonalny, czy starały się - za realistami - chronić pokój i równowagę we współpracy z aliantami, moderując konflikty z antagonistami, to we własnej sile widziały instrument utrzymania pożądanej stabilności w świecie.

7 Na forum koreańskiego parlamentu Trump zafałszował historię Korei Płd., wymazując erę - popieranej przez USA - dyktatury [White House, 2017].

8 Tak powiedział prezydent Roosevelt - w rozmowie z sekretarzem Stanu - na temat Somozy: "Sumner Welles, once said «Somoza's a bastard!» And Roosevelt replied, "Yes, but he's our bastard»" [Wikiquote, 2017]. 
Spór pomiędzy idealistami a zwolennikami kierowania się interesem narodowym był istotny dla USA, ale nie wywoływał turbulencji w świecie9 .

Można uznać, że w okresie po II wojnie światowej w działalności na forum międzynarodowym USA racjonalnie zarządzały zasobami, odróżniając stany i sytuacje, w których ich bezpośredni udział był konieczny, od tych, w których był on (tylko) pomocny. Relatywnie skutecznie, w perspektywie dłuższej niż krótkoterminowa, unikały antagonizowania aliantów i ewolucji antagonistów we wrogów. Dzięki temu w grze strategicznej USA zwiększały liczbę "pól" (państw/spraw), które obejmowały swoimi wpływami, redukując "pola”, do których dostęp mieli ich antagoniści ${ }^{10}$. Strategia USA w tak prowadzonej grze była ostrożna, zmuszając do umiarkowania innych graczy (szczególnie antagonistów i wrogów). Pomimo braku bezpieczeństwa i stabilności w latach 1945-2017 świat uniknął konfliktu globalnego, m.in. dzięki wykonywaniu przez USA zobowiązań międzynarodowych oraz utrzymywaniu parasola nad aliantami i obszarami strategicznych interesów ${ }^{11}$.

Polityka ta nie uwalniała jednak ani USA, ani świata od dylematów. Wymagała współodpowiedzialności - również finansowej - aliantów za bezpieczeństwo w formule "kolektywnej samoobrony". Tej współodpowiedzialności nie wymagały USA od państw zlokalizowanych w strefach o strategicznym znaczeniu dla bezpieczeństwa własnego. Te czynniki decydowały o tym, że USA w przestrzeni transatlantyckiej korzystały z instrumentów polityki multilateralnej, co ułatwiało instytucjonalizację współpracy regionalnej. W regionie Pacyfiku dominowały natomiast metody i narzędzia unilateralne, utrwalające postawy państw tego regionu niechętne współpracy $\mathrm{w}$ ramach organizacji międzynarodowych. Upadek ZSRR i rozpad bloku wschodniego obniżyły poziom zagrożeń w strefie odpowiedzialności NATO.

Od 1989 r. źródła nuklearnych zagrożeń dla USA i ich sojuszników znajdują się w Korei Płn. i Iranie, a więc państwach, które odrzucają zarówno zakaz agresji, jak i reżim nieproliferacji oraz popierają terroryzm międzynarodowy. Te państwa współtworzą przestrzeń niestabilności, promieniują na otoczenie, co zmusiło USA do przypisania im wysokiego priorytetu. Logicznym następstwem był więc "pivot to Asia" [Lieberthal, 2011]. W tej strategii eksponowano wzrost znaczenia regionu, a kamuflowano jej reaktywny, militarno-obronny charakter. Strategia ta, planowana na ponad 60 lat, miała obejmować relokację zasobów - pozostawienie w regionie Azji zasobów wykorzystanych w wojnach w Iraku i Afganistanie.

9 Te podobieństwa ujawnia porównanie wartości i celów prezydentów Wilsona i Nixona [Kissinger, 1996, s. 775-778].

${ }^{10}$ Posiłkowano się więc strategią szachów, jednak USA preferowały strategię win-win.

${ }^{11}$ Każda próba zwinięcia parasola tylko podnosiła koszt przywrócenia status quo ante, jak np. w przypadku obrony Korei Płd. czy Kuwejtu. 
Tę politykę odrzucił prezydent Trump. Nowa polityka (również w regionie Azji i Pacyfiku) miała chronić interesy USA - przede wszystkim gospodarcze i doprowadzić do parytetu nakładów na bezpieczeństwo pomiędzy USA i sojusznikami, zdaniem Trumpa bowiem polityka poprzedników zaowocowała wzrostem potęgi innych państw kosztem USA. Strategię „pivot to Asia” miały zastąpić obrona i wspieranie interesów gospodarczych i politycznych USA. Stanowiąca jej podstawę ocena relacji korzyści/kosztów sojuszy z partnerami strategicznymi w Azji była jednoznacznie negatywna. Sformułowano zarzut, że otwarcie rynku amerykańskiego nie spotkało się z wzajemnością, a obronne nakłady osobowe i rzeczowe USA były nieproporcjonalnie wysokie w stosunku do nakładów sojuszników. USA chciały radykalnie zmienić tę sytuację, bardzo szybko zostały jednak skonfrontowane ze strategicznym wyzwaniem w postaci przeprowadzenia przez Koreę Płn. testu bomby wodorowej [NORSAR, 2017] oraz uzyskania przez nią zdolności do zaatakowania terytorium USA z użyciem ładunków niekonwencjonalnych. W reakcji USA tak szybko, jak ogłosiły odwrót od Azji, tak rozpoczęły powrót - do sojuszu strategicznego z Japonią, Koreą Płd., Australią i Nową Zelandią.

Powrotowi towarzyszy jednak zmiana co najmniej terminologii, jeśli nie polityki. W miejsce „Azja-Pacyfik” w nazwie regionu pojawia się „Indo-Pacyfik”12. Nie towarzyszy temu przedstawienie spójnej strategii, dowodzi jednak chęci zmian. Prima facie wyraża niechęć do terminologii Baracka Obamy. Jeśli jednak tylko takie są przyczyny, to skutki są poważniejsze. Po pierwsze, w wersji pierwotnej termin odnosił się tylko do bezpieczeństwa żeglugi, trudno więc objąć nim automatycznie nowe komponenty. Po drugie, objęcie współpracą Indii ${ }^{13}$ (i niezaproszenie Pakistanu) antagonizuje świat muzułmański ${ }^{14}$ i nadaje współpracy wymiar antychiński, nie przynosząc czytelnych korzyści. Oczywiście można wskazać argumenty na rzecz zaproszenia Indii do współpracy [szerzej: Jaipragas, 2017], trudno jednak o gorszy moment na wyeksponowanie antychińskiego ostrza sojuszu [Medcalf, 2013] niż ten, kiedy USA oczekują wsparcia ze strony Chin w konflikcie z Koreą Płn. ${ }^{15}$

Donald Trump zdaje się biernie podążać za cudzymi inicjatywami. Terminem "Indo-Pacyfik" nawiązał do idei premiera Japonii Shinzo Abe opisującego region jako „Asia's democratic security diamond”. Nie są to jednak jedyne słabości koncepcji Trumpa. Nie poprzedziły jej bowiem ani uzgodnienia z Indiami ${ }^{16}$, ani dostrzeże-

12 Autor, oficer marynarki Indii Gurpeet S. Khurana, odnosił go do morskich szlaków żeglugowych [Khurana, 2007, s. 139].

13 Państwa, którego nie było w sojuszu z USA, złamało reżim NPT i ewoluuje w kierunku autorytarnej republiki religijnej.

${ }^{14}$ W kontekście rozważań kluczowe znaczenie ma reakcja Filipin.

15 Sekretarz stanu USA Rex Tillerson stwierdził, że chińskie prowokacje na Morzu Południowochińskim, łamiące prawo międzynarodowe, są wymierzone nie tylko w suwerenność sąsiadów, lecz także szkodzą interesom USA i ich przyjaciół [szerzej zob. Gaouette, 2017; Viray, 2017].

${ }^{16} \mathrm{Na}$ temat stanowiska Indii zob. [Eyal, 2016]. 
nie istoty inicjatywy rządu japońskiego, kiedy minister spraw zagranicznych Japonii Taro Kono zaprosił do współpracy Francję i Wielką Brytanię [Asian Review, 2017]. W reakcji na neoizolacjonizm USA Japonia opowiedziała się za instytucjonalizacją multilateralizmu. Wycofanie amerykańskich gwarancji bezpieczeństwa ma rekompensować współpraca, którą zapoczątkowało (w maju 2017 r.) patrolowanie wód Pacyfiku przez floty USA, Japonii, Francji i Wielkiej Brytanii [Hutt, 2017]. Reakcje europejskich sojuszników na zaproszenie są jednoznacznie pozytywne ${ }^{17}$.

Celem nowej polityki i wyznaczenia nowego regionu jest położenie kresu erze braku równowagi w handlu (stan taki ma miejsce, zdaniem Trumpa, obecnie) i umożliwienie konkurowania „on fair and equal basis”. USA zapowiedziały reagowanie na nierówność w dostępie do rynku, dumping i subsydia oraz ochronę własności intelektualnej [Remarks at APEC CEO Summit, 2017]. Są to wyłącznie pojedyncze elementy polityki gospodarczej, brakuje jednak strategii oraz powiązania polityki gospodarczej z innymi sferami polityki (np. w dziedzinie bezpieczeństwa lub obrony).

\section{Analiza wskaźników obrazujących wspólne wartości}

Analizujemy wskaźniki obrazujące wspólne (lub różne) wartości 11 państw TPP, państw, które zgłaszają chęć przystąpienia do ugrupowania, oraz USA.

Zaczynamy od wskaźnika rozwoju społeczno-gospodarczego (Human Development Index-HDI), który pozwala na podział analizowanych krajów na trzy grupy, w zależności od osiągniętego w 2015 r. wyniku HDI ${ }^{18}$. Są to państwa o bardzo wysokim poziomie rozwoju ludzkiego: Australia, Brunei, Chile, Japonia, Kanada, Korea Płd., Nowa Zelandia, Singapur i USA; państwa o wysokim HDI: Kolumbia, Malezja, Meksyk, Peru, Sri Lanka i Tajlandia oraz państwa o średnim HDI: Bangladesz, Filipiny, Indie, Indonezja, Kambodża, Laos i Wietnam. Żaden kraj z regionu nie znalazł się w grupie państw o niskim HDI (rys. 2).

Kolejny z badanych wskaźników - Indeks wolności (Human Freedom Index HFI) - szereguje państwa w zależności od przestrzegania i ochrony przez nie praw politycznych i swobód obywatelskich. Maksymalna liczba punktów, którą może zdobyć państwo w obu kategoriach łącznie, wynosi 100. Ponadto w obu kategoriach państwa otrzymują od 1 do 7 punktów, a średnia z obu wartości nazywana jest wskaźnikiem wolności i stanowi podstawę klasyfikacji państw na wolne, częściowo wolne i pozbawione wolności (tab. 1).

\footnotetext{
17 Komentarz zob. [Stanley, 2016; Johnson, 2016; Scott, 2017].

18 Pozwala on na pełniejszą ocenę poziomu rozwoju niż PKB per capita, gdyż bierze pod uwagę także sferę zdrowia i edukacji. HDI wykorzystuje się m.in. do porównań dystansu między krajami najuboższymi i najbogatszymi.
} 


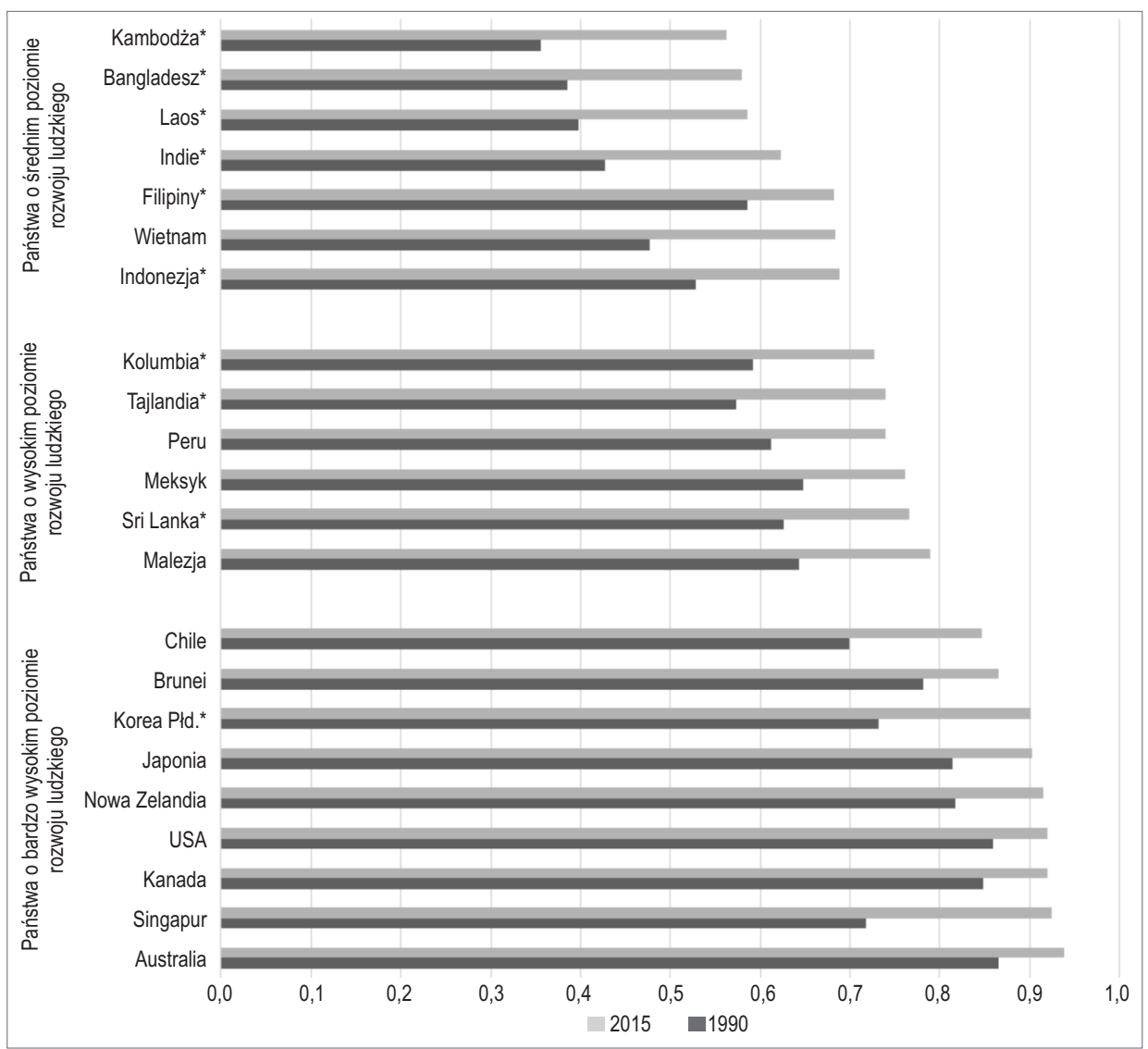

* Państwa zainteresowane członkostwem w TPP.

Rysunek 2. Wskaźnik rozwoju społecznego według UNDP w wybranych państwach w latach 1990-2015

Źródło: Opracowanie własne na podstawie: [Human Development Index, 2016].

Sumaryczna liczba punktów uzyskana w 2017 r. przez wybrane do badania państwa przedstawiona została na rysunku 3. Kanada, Australia, Nowa Zelandia, Japonia, Chile oraz USA uzyskały wyniki powyżej 85. Na drugim biegunie znalazły się Laos, Wietnam i Brunei, osiągając poniżej 30 punktów.

Obrazu dopełnia kolejny wskaźnik wolności, który oprócz wolności osobistych (jak ochrona i przestrzeganie prawa, wolność swobodnego poruszania się, wyznania, stowarzyszania się i słowa, prawa w zakresie związków) obejmuje także wolności gospodarcze (wydatki rządowe, wielkość obciążeń podatkowych, prawa własności, polityka monetarna, wolność handlu międzynarodowego i działalności gospodarczej, swoboda inwestycji zagranicznych, regulacje rynku 
pracy), które łącznie składają się na Indeks wolności. Wartości przyjmowane przez HFI mieszczą się w przedziale od 0 do 10, gdzie 10 oznacza więcej wolności.

Tabela 1. Stopień przestrzegania i ochrony praw politycznych i swobód obywatelskich w państwach regionu Pacyfiku i USA w 2017 r.

\begin{tabular}{|c|c|c|c|}
\hline Państwo & $\begin{array}{c}\text { Wskaźnik } \\
\text { praw politycznych }\end{array}$ & $\begin{array}{c}\text { Wskaźnik swobód } \\
\text { obywatelskich }\end{array}$ & Klasyfikacja państwa \\
\hline Australia & 1 & 1 & $\mathrm{~F}$ \\
\hline Bangladesz ${ }^{*}$ & 4 & 4 & $\mathrm{PF}$ \\
\hline Brunei & 6 & 5 & $\mathrm{NF}$ \\
\hline Chile & 1 & 1 & $\mathrm{~F}$ \\
\hline Filipiny* & 3 & 3 & $\mathrm{PF}$ \\
\hline Indie* & 2 & 3 & $\mathrm{~F}$ \\
\hline Indonezja* & 2 & 4 & PF \\
\hline Japonia & 1 & 1 & $\mathrm{~F}$ \\
\hline Kambodża* & 6 & 5 & $\mathrm{NF}$ \\
\hline Kanada & 1 & 1 & $\mathrm{~F}$ \\
\hline Kolumbia* & 3 & 3 & PF \\
\hline Korea Płd.* & 2 & 2 & $\mathrm{~F}$ \\
\hline Laos* & 7 & 6 & NF \\
\hline Malezja & 4 & 4 & $\mathrm{PF}$ \\
\hline Meksyk & 3 & 3 & PF \\
\hline Nowa Zelandia & 1 & 1 & $\mathrm{~F}$ \\
\hline Peru & 2 & 3 & $\mathrm{~F}$ \\
\hline Singapur & 4 & 4 & $\mathrm{PF}$ \\
\hline Sri Lanka* & 3 & 3 & $\mathrm{PF}$ \\
\hline Tajlandia* & 6 & 5 & $\mathrm{NF}$ \\
\hline USA & 2 & 1 & $\mathrm{~F}$ \\
\hline Wietnam & 7 & 5 & NF \\
\hline
\end{tabular}

* Państwa zainteresowane członkostwem w TPP.

Uwaga: wskaźniki przyjmują wartości od 1 (najlepszy wynik) do 7 (najgorszy wynik).

Klasyfikacja państw: F - wolne, PF - częściowo wolne, NF - pozbawione wolności

Źródło: Opracowanie własne na podstawie: [Freedom in the World, 2018].

Państwa regionu Pacyfiku znacznie różnią się między sobą poziomem wskaźników (tab. 2). Najwyższe wyniki osiągają te same państwa, co w przypadku poprzednio analizowanego Indeksu wolności, potwierdzając podobieństwa wartości w państwach rozwiniętych i różnice między nimi a uboższymi krajami regionu Pacyfiku. 


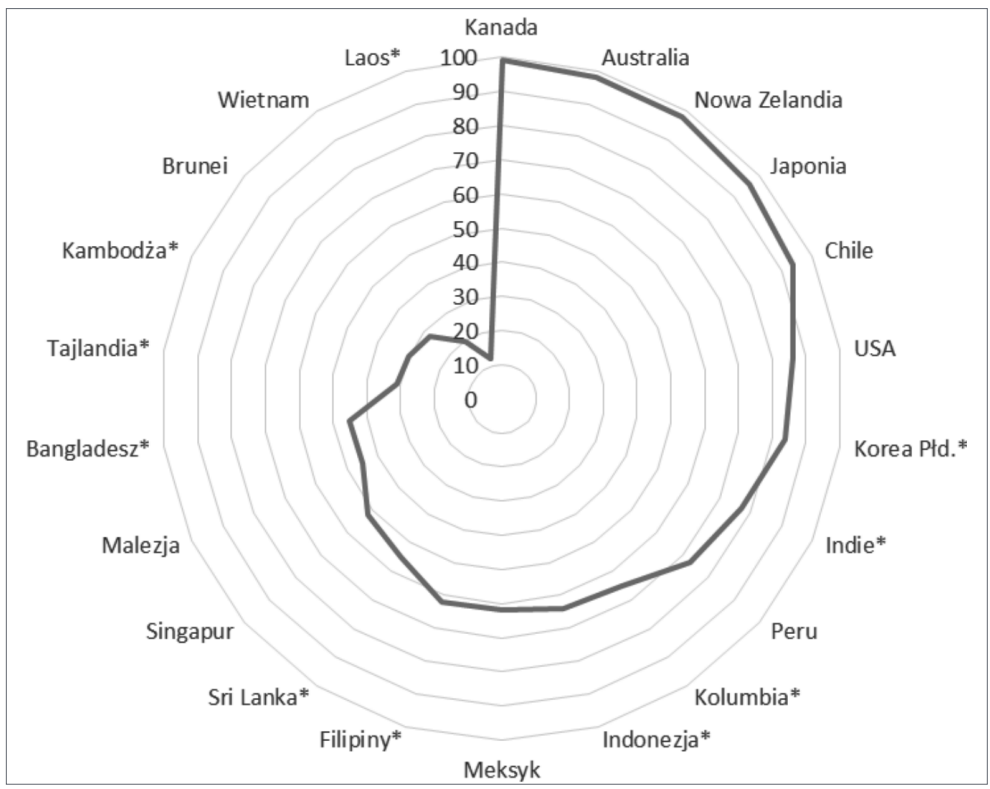

* Państwa zainteresowane członkostwem w TPP.

Rysunek 3. Wskaźnik wolności według Freedom House w państwach regionu Pacyfiku i USA w 2017 r.

Źródło: Opracowanie własne na podstawie: [Freedom in the World, 2018].

Tabela 2. Wskaźnik wolności według Cato Institute w państwach regionu Pacyfiku i USA w 2015 r.

\begin{tabular}{|l|c|c|c|c|}
\hline \multicolumn{1}{|c|}{ Państwo } & $\begin{array}{c}\text { Wolność } \\
\text { osobista }\end{array}$ & $\begin{array}{c}\text { Wolność } \\
\text { gospodarcza }\end{array}$ & $\begin{array}{c}\text { Wskaźnik wol- } \\
\text { ności ludzkiej } \\
\text { (HFI) }\end{array}$ & $\begin{array}{c}\text { Miejsce } \\
\text { w rankingu } \\
\text { HFI }\end{array}$ \\
\hline Nowa Zelandia & 9,25 & 8,48 & 8,86 & 3 \\
\hline Australia & 9,22 & 7,99 & 8,60 & 5 \\
\hline Kanada & 9,13 & 7,94 & 8,54 & 11 \\
\hline USA & 8,83 & 7,94 & 8,39 & 17 \\
\hline Singapur & 7,86 & 8,81 & 8,34 & 18 \\
\hline Japonia & 8,93 & 7,47 & 8,20 & 27 \\
\hline Korea Płd.* & 8,79 & 7,54 & 8,17 & 29 \\
\hline Chile & 8,23 & 7,77 & 8,00 & 37 \\
\hline Peru & 7,44 & 7,44 & 7,44 & 51 \\
\hline Kambodża* & 7,26 & 7,21 & 7,23 & 58 \\
\hline Filipiny* & 6,46 & 7,47 & 6,97 & 71 \\
\hline Meksyk & 6,92 & 6,95 & 6,93 & 73 \\
\hline Indonezja* $^{*}$ & 6,67 & 7,00 & 6,83 & 78 \\
\hline Kolumbia* & 6,90 & 6,40 & 6,65 & 93 \\
\hline
\end{tabular}




\begin{tabular}{|l|c|c|c|c|}
\hline \multicolumn{1}{|c|}{ Państwo } & $\begin{array}{c}\text { Wolność } \\
\text { osobista }\end{array}$ & $\begin{array}{c}\text { Wolność } \\
\text { gospodarcza }\end{array}$ & $\begin{array}{c}\text { Wskaźnik wol- } \\
\text { ności ludzkiej } \\
\text { (HFI) }\end{array}$ & $\begin{array}{c}\text { Miejsce } \\
\text { w rankingu } \\
\text { HFI }\end{array}$ \\
\hline Malezja & 6,02 & 7,19 & 6,61 & 97 \\
\hline Indie* & 6,46 & 6,63 & 6,55 & 102 \\
\hline Tajlandia* & 6,29 & 6,75 & 6,52 & 105 \\
\hline Laos* $^{*}$ & 5,98 & 6,98 & 6,48 & 106 \\
\hline Brunei & 6,08 & 6,76 & 6,42 & 115 \\
\hline Wietnam & 6,05 & 6,30 & 6,17 & 124 \\
\hline Bangladesz* & 5,52 & 6,32 & 5,92 & 133 \\
\hline Sri Lanka* & 5,17 & 6,65 & 5,91 & 135 \\
\hline
\end{tabular}

* Państwa zainteresowane członkostwem w TPP.

Uwaga: ostatnie dostępne dane są za 2015 r.

Źródło: Opracowanie własne na podstawie: [Vásquez, Porčnik, 2017].

Połączone dane na temat wskaźnika wolności oraz wskaźnika demokracji dowodzą związku między wolnością a demokracją (rys. 4). Nie jest znany kierunek zależności między obiema zmiennymi, jak również wpływ innych czynników (np. poziomu rozwoju gospodarczego), ale można zauważyć, że wśród krajów o umiarkowanym poziomie wolności ludzkiej (i jednocześnie niższym poziomie rozwoju) występują duże różnice w poziomie demokracji (tu rozumianej jako proces wyborczy i pluralizm, funkcjonowanie rządu, uczestnictwo polityczne i kultura polityczna). Najbardziej skrajne przykłady to Laos z jednej strony i Indie z drugiej.

\section{Podsumowanie}

Państwa regionu Pacyfiku skonfrontowane z poważnymi wyzwaniami (m.in. zmiana polityki USA, dążenie Chin do przywództwa, agresywna polityka Korei Płn.) nie tylko okazały się zdolne do kontynuowania współpracy (TPP11), lecz także do działań na rzecz jej pogłębienia i poszerzenia ( $w$ tym na partnerów spoza regionu). Można to uznać za prognostyk ustanowienia nowej formuły współpracy w regionie - współpracy zinstytucjonalizowanej. Doświadczenia europejskie i transatlantyckie wskazują na to, że geograficzna bliskość nie wystarcza, by taka współpraca została nawiązana, lecz że warunkiem koniecznym jej zaistnienia jest wspólnota wartości. Badanie potwierdza potencjał państw regionu do instytucjonalizacji współpracy na fundamencie wartości. Zdolność do współpracy, wola polityczna i potencjał gospodarczy mogą zadecydować o wadze instytucji powołanych przez badane państwa. Barierą może okazać się niezdolność do przepracowania przeszłości. Zagrożenia mogą wynikać $\mathrm{z}$ niestabilności, w tym pochodnej zmian $\mathrm{w}$ polityce USA. 


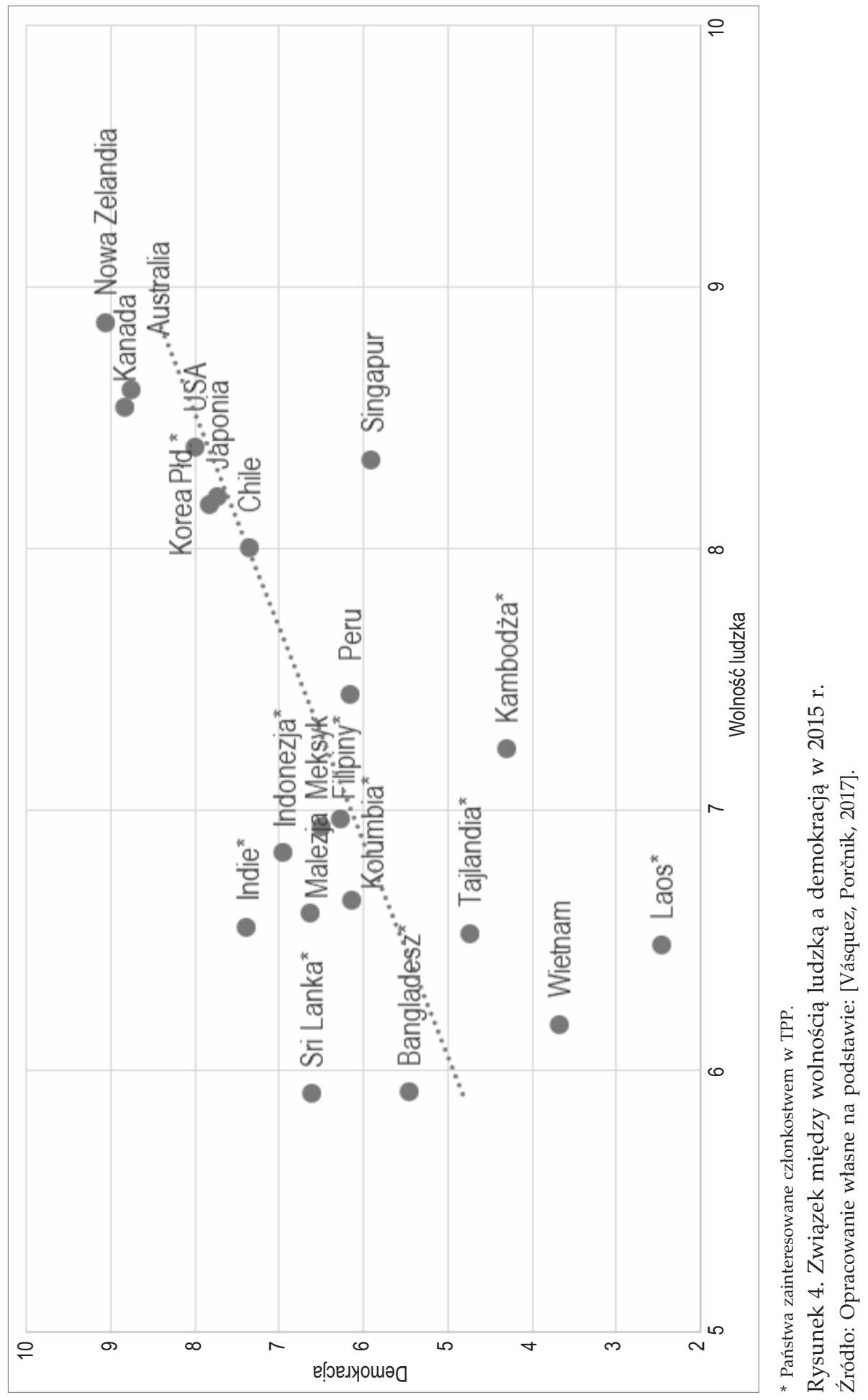




\section{Bibliografia}

America First Foreign Policy, 2017, https://www.whitehouse.gov/america-first-foreignpolicy [dostęp: 24.06.2017].

Asian Review, 2017, October 25, https://asia.nikkei.com/Politics-Economy/InternationalRelations/Japan-to-propose-dialogue-with-US-India-and-Australia [dostęp: 24.11.2017].

Baker P., 2017, Trump Says NATO Allies Don't Pay Their Share. Is That True?, The New York Times, May 26.

Capaldo J., 2015, TTIP. European Disintegration, Unemployment and Instability, Economia \& Lavoro, August.

Capaldo J., Izurieta A., Sundaram J.K., 2016, Trading down. Unemployment, Inequality and other risks of the Trans-Pacific Partnership Agreement, Global Development and Environmental Institute Working Paper, no. 16-01.

CNBC, 2018, January 25, https://www.cnbc.com/2018/01/25/trump-says-he-would-reconsider-trans-pacific-partnership-trade-deal.html [dostęp: 28.01.2018].

Collinson S., 2017, Trump New action coming on security next week, CNN, https:/edition. cnn.com/2017/02/10/politics/trump-abe-press-conference/index.html [dostęp: 24.11.2017].

Cronin P.M., 2017, Trump's Post-Pivot Strategy, The Diplomate, November 11.

Eisenhower D.D., 1954, The President's News Conference, April 7, Online by Gerhard Peters and John T. Woolley, The American Presidency Project, http://www.presidency. ucsb.edu/ws/?pid=10202 [dostęp: 24.11.2017].

Erixon F., Bauer M., 2015, "Splendid Isolation” as trade policy. Mercantilism and Crude Keynesianism in the "Capaldo Study" of TTIP, European Center for International Political Economy, April.

Eyal J., 2016, Japan-India. An Alliance with a difference, The Straits Time, November 7.

Freedom in the World, 2018, Freedom House, https://freedomhouse.org/report-types/freedom-world [dostęp: 10.02.2018].

Gaouette N., 2017, Tillerson raps China as 'predatory' rule breaker, CNN Politics, October 19.

Green J., Goodman M.P., 2015, After TPP. The Geopolitics of Asia and Pacific, The Washington Quarterly, vol. 38, issue 4.

Gregory J., 2018, Britain exploring membership of the TPP to boost trade after Brexit, The Guardian, January 3.

Human Development Index, 2016, http://hdr.undp.org/en/composite/trends [dostęp: 10.02.2018].

Hutt D., 2017, The 'Indo-Pacific' Vision. Room For Britain And France?, Forbes, November 14.

Jaipragas B., 2017, Why is the US calling Asia-Pacific the Indo-Pacific? Donald Trump to 'Clarify', November 7, http://www.scmp.com/week-asia/politics/article/2118806/why-us-callingasia-pacific-indo-pacific-trump-clarify [dostęp: 10.01.2018].

Johnson B., 2016, Britain is back East of Suez, December 9, https://www.gov.uk/government/ speeches/foreign-secretary-speech-britain-is-back-east-of-suez [dostęp: 10.11.2017].

Johnston A.I., 1995, Thing about Strategic Culture, International Security, vol. 19, no. 4.

Karta Narodów Zjednoczonych, 1945, http://libr.sejm.gov.pl/tek01/txt/onz/1945.html [dostęp: 10.10.2017].

Khurana G.S., 2007, Security of sea Lines. Prospects for India-Japan Cooperation, Strategic Analysis, vol. 31 , no. 1 . 
Kissinger H., 1996, Dyplomacja, Philip Wilson, Warszawa.

Lieberthal K., 2011, The American Pivot to Asia, Foreign Policy, December 21.

Medcalf R., 2013, The Indo-Pacific. What's in a Name?, Brookings, October, https://www.brookings.edu/articles/the-indo-pacific-whats-in-a-name/ [dostęp: 16.06.2017].

Naughtoton B., Kroeber A.R., de Jonquieres G., Webster G., 2015, What will the TPP mean for China? The agreement could indirectly spur Chinese economic reform, but may also pull its neighbors closer to the United States, Foreign Policy, October 7.

NORSAR, 2017, The nuclear explosion in North Korea on 3 September: A revised magnitude assessment, September 12, https://www.norsar.no/press/latest-press-release/archive/thenuclear-explosion-in-north-korea-on-3-september-2017-a-revised-magnitude-assessmentarticle1548-984.html [dostęp: 06.12.2017].

Palit A., 2014, The Trans Pacific Partnership, China and India. Economic and Political Implications, Routledge, New York.

Pew Global Attitudes \& Trends Question Database, 2018, http://www.pewglobal.org/question-search/?qid=2101\&cntIDs=\&stdIDs [dostęp: 06.02.2018].

Presidential Memorandum regarding withdrawal of the United States from Trans-Pacific Partnership Negotiations and Agreement, 2017, January 23, https://www.whitehouse. gov/presidential-actions/presidential-memorandum-regarding-withdrawal-united-statestrans-pacific-partnership-negotiations-agreement/ [dostęp: 06.02.2018].

Pye L.W., 1990, China. Erratic State, frustrated Society, Foreign Affairs, vol. 69, no. 4.

Remarks at APEC CEO Summit, 2017, https://www.whitehouse.gov/the-press-office/2017/ 11/10/remarks-president-trump-apec-ceo-summit-da-nang-vietnam [dostęp: 05.11.2017].

Sanger D.E., Haberman M., 2016, Donald Trump sets conditions for defending NATO Allies against attack, New York Times, July 20.

Scott D., 2017, French maritime Strategic thought on the Indo-Pacific, Center for International Maritime Security, March 31.

Stanley T., 2016, Boris of Arabia? Johnson's plan to restore Britain 'east of Suez' is audacious, The Telegraph, December 10.

USITC, 2016, Trans-Pacific Partnership Agreement. Likely Impact on the U.S. Economy and on Specific Industry Sectors, May, no. 4607.

Vásquez I., Porčnik T., 2017, The Human Freedom Index 2017, Cato Institute, Fraser Institute, Friedrich Naumann Foundation for Freedom.

Viray P.L., 2017, US. We will not ignore China's challenge to rules-based order, The Philippine Star, October 19.

White House, 2017, Remarks by President Trump to the National Assembly of the Republic of Korea, Seoul, November 7, https://www.whitehouse.gov/the-press-office/2017/11/07/ remarks-president-trump-national-assembly-republic-korea-seoul-republic [dostęp: 05.12.2017].

Wikiquote, 2017, https://en.wikiquote.org/wiki/Talk:Franklin_D._Roosevelt [dostęp: 10.06.2017]. World Bank, 2016, Potential Macroeconomic Implications on the Trans-Pacific Partnership. Global Economic Prospects, January, Chapter 4.

A. Kuźnar (『) akuzna@sgh.waw.pl

Szkoła Główna Handlowa w Warszawie, al. Niepodległości 162, 02-554 Warszawa, Polska

J. Menkes, Szkoła Główna Handlowa w Warszawie, al. Niepodległości 162,

02-554 Warszawa, Polska 